
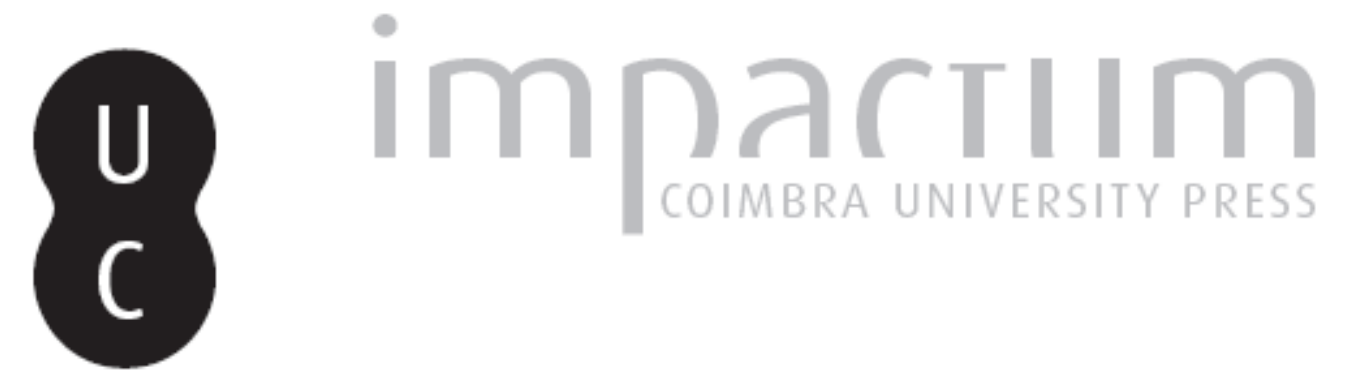

\title{
A Corte de D. Sancho II (1223-1248)
}

\section{Autor(es): $\quad$ Rocha, Ana Rita}

Publicado por: Faculdade de Letras da Universidade de Coimbra, Instituto de História Económica e Social

URL persistente:

URI:http://hdl.handle.net/10316.2/33431

DOI:

DOI:http://dx.doi.org/10.14195/0870-4147_44_5

Accessed : $\quad$ 26-Apr-2023 15:32:55

A navegação consulta e descarregamento dos títulos inseridos nas Bibliotecas Digitais UC Digitalis, UC Pombalina e UC Impactum, pressupõem a aceitação plena e sem reservas dos Termos e Condições de Uso destas Bibliotecas Digitais, disponíveis em https://digitalis.uc.pt/pt-pt/termos.

Conforme exposto nos referidos Termos e Condições de Uso, o descarregamento de títulos de acesso restrito requer uma licença válida de autorização devendo o utilizador aceder ao(s) documento(s) a partir de um endereço de IP da instituição detentora da supramencionada licença.

Ao utilizador é apenas permitido o descarregamento para uso pessoal, pelo que o emprego do(s) título(s) descarregado(s) para outro fim, designadamente comercial, carece de autorização do respetivo autor ou editor da obra.

Na medida em que todas as obras da UC Digitalis se encontram protegidas pelo Código do Direito de Autor e Direitos Conexos e demais legislação aplicável, toda a cópia, parcial ou total, deste documento, nos casos em que é legalmente admitida, deverá conter ou fazer-se acompanhar por este aviso.

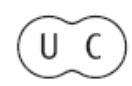




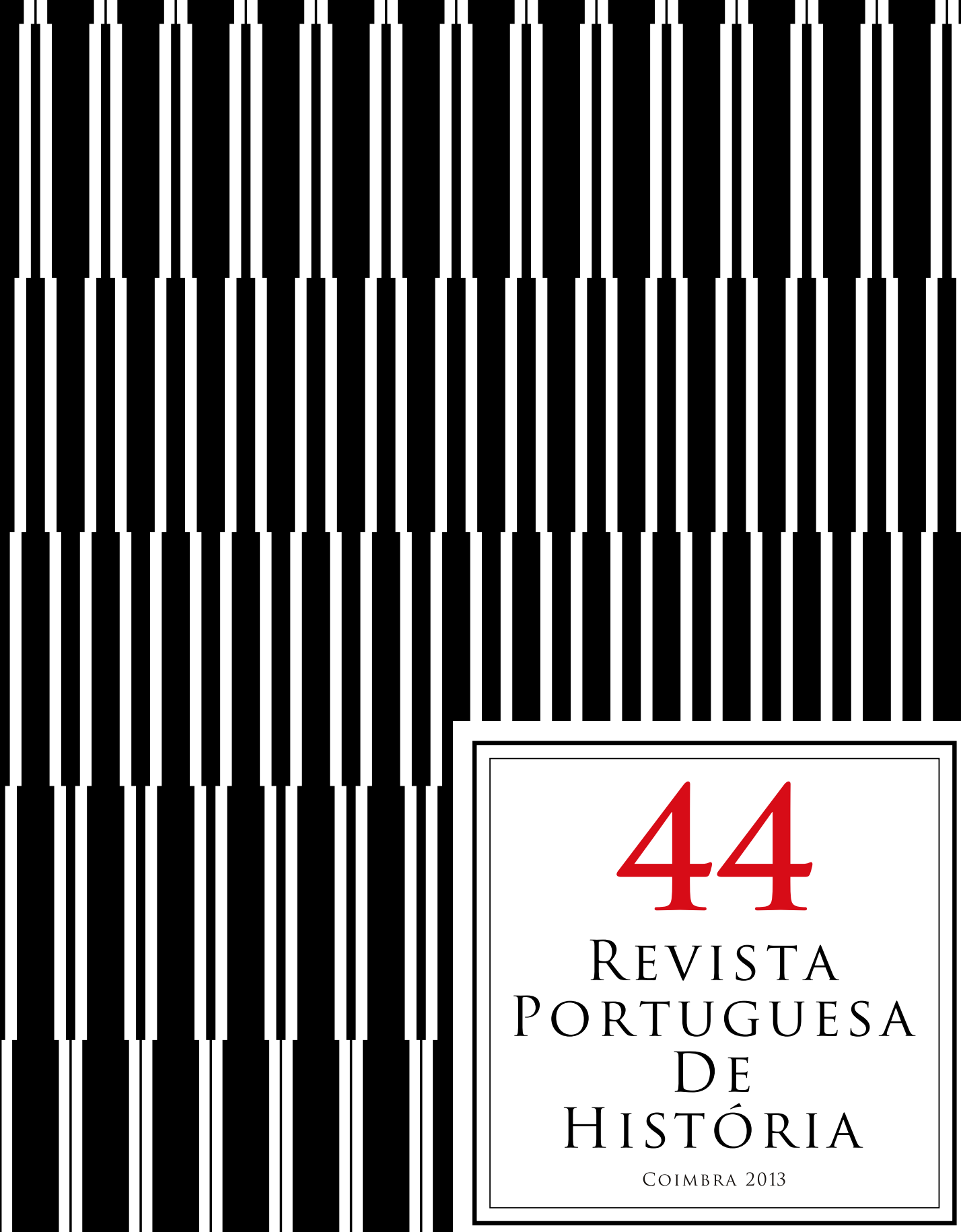




\title{
A Corte de D. Sancho II (1223-1248)*
}

\author{
Ana Rita Rocha \\ Doutoranda em Altos Estudos em História - Idade Média \\ Universidade de Coimbra \\ anarita.srocha@gmail.com
}

Resumo:

$\mathrm{Na}$ esteira dos estudos sobre a corte medieval portuguesa em diferentes reinados, o presente artigo tem por objectivo analisar a de D. Sancho II (1223-1248), atendendo à sua estrutura e aos indivíduos provenientes da nobreza e do clero, que rodeavam o monarca. Recorrendo à documentação emanada da chancelaria régia, perceberemos quem constava nas listas finais de confirmantes e que, marcando presença nas assembleias, auxiliava o monarca nas suas decisões. Pretendemos, assim, perceber que oficiais estavam responsáveis pelas principais funções administrativas da cúria e quem eram os nobres e eclesiásticos que constituíam a designada entourage real. Para isso, não podemos deixar de enquadrar a evolução da corte nas circunstâncias de crise política e social que se viveram ao longo do reinado.

Palavras chave:

Corte; D. Sancho II; Ofícios Curiais; Nobreza de Corte; Clero de Corte.

\section{Abstract:}

Following the research about the medieval portuguese court in some different reigns, this paper aims to analyze the court of D. Sancho II (1223-1248), with a focus on its structure and on the individuals from nobility and clergy who surrounded the king. Based on sources from the royal chancery, we will realize who composed the final lists of confirmation and who helped the king in his decisions, once they were at the assemblies. We intend, therefore, to understand which officials were responsible for the major administrative functions of the curia and who were the nobles and ecclesiastics that composed the so called royal entourage. For this, we must intertwine the court evolution in the political and social crisis that marked this reign.

Keywords:

Court; D. Sancho II; Curial Offices; Court Nobility; Court Clergy.

* Este artigo tem por base o trabalho realizado no seminário "A Corte Régia", no âmbito do Mestrado em História da Idade Média - Espaços, Poderes, Quotidianos, no ano lectivo de 2009-2010, leccionado pela Prof. Doutora Leontina Ventura, a quem agradecemos o apoio e sugestões indispensáveis à preparação deste estudo. A nossa gratidão estende-se também, pela ajuda e incentivo, à Marta Santos, ao Roger Lee de Jesus, ao Miguel e à nossa família. 


\section{Introdução}

D. Sancho II ascendeu ao trono em 1223, com cerca de 13 anos, sucedendo a seu pai, D. Afonso II, de quem herdou um reino mergulhado numa profunda crise política e social. De facto, as políticas de centralização do poder que vinham sendo empreendidas originaram violentos conflitos entre a Coroa e os principais grupos sociais (nobreza e clero) ${ }^{1}$. Numa tal conjuntura, $O$ Capelo teve de solucionar muitos dos problemas que vinham do reinado de seu pai e enfrentar aqueles que, destituídos do seu anterior poder, tudo fizeram para o retomar, aproveitando-se da menoridade do monarca. Para isso, contou com o apoio das famílias que haviam ascendido à corte graças à acção de D. Afonso e que pretendiam manter a sua posição. A crescente instabilidade daí resultante conduziu a uma guerra civil entre os anos de 1245 e 1248, que terminou com a deposição, exílio e morte do rei, a quem sucedeu o irmão, D. Afonso III² .

A composição da corte de D. Sancho II, entre 1223 e 1248, que aqui pretendemos analisar, reflecte, nitidamente, todas as convulsões que atravessaram o seu reinado. Desde os oficiais mores da administração régia aos membros das principais linhagens nobres e aos prelados que marcavam presença nas reuniões curiais, a corte d' $O$ Capelo sofreu muitas e profundas alterações, que lhe conferem um carácter particular no panorama medieval português.

\section{Estrutura da Corte de D. Sancho II}

O conceito medieval de corte (curia) abrangia quer o grupo de indivíduos que assessorava o monarca nos assuntos da governação, quer a residência

1 Para uma contextualização do reinado de D. Afonso II veja-se, sobretudo, Maria Teresa Nobre Veloso, “As Primeiras Medidas na Senda do Centralismo", in Joel Serrão e A. H. de Oliveira Marques (dir.), Nova História de Portugal, Maria Helena da Cruz Coelho e Armando Luís de Carvalho Homem (coord.), vol. III, Portugal em Definição de Fronteiras (1096-1325). Do Condado Portucalense à Crise do Século XIV, Lisboa, Editorial Presença, 1996, p. 89-103 e Hermínia Vasconcelos Vilar, D. Afonso II: Um rei sem tempo, Rio de Mouro, Temas e Debates, 2008.

2 Entre os estudos que oferecem uma contextualização do reinado de D. Sancho II sugere-se a consulta de Leontina Ventura, "A Crise de Meados do Século XIII", in Joel Serrão e A. H. de Oliveira Marques (dir.), Nova História de Portugal, Maria Helena da Cruz Coelho e Armando Luís de Carvalho Homem (coord.), vol. III, Portugal em Definição de Fronteiras (1096-1325). Do Condado Portucalense à Crise do Século XIV, Lisboa, Editorial Presença, 1996, p. 104-123 e Hermenegildo Fernandes, D. Sancho II: Tragédia, Lisboa, Temas e Debates, 2010. Para uma abordagem específica sobre a Guerra Civil de 1245-1248, veja-se Miguel Gomes Martins, De Ourique a Aljubarrota: A Guerra na Idade Média, Lisboa, A Esfera dos Livros, 2011, p. 147-167. 
deste e desses seus conselheiros e oficiais domésticos, o palácio (palatium) ${ }^{3}$. A presença destes vassalos no espaço régio aponta para a privatização do poder, que "não permite ao senhor governar arbitrariamente", mas sim com "o acordo e a colaboração dos seus homens"4. Segundo Georges Duby, este órgão superior do governo do reino constitui o modelo primeiro de toda a vida social organizada ${ }^{5}$. Nela se reuniam nobres e clérigos que tanto podiam ocupar ofícios superiores da administração, como exercer as funções de conselheiros e estabelecer a ligação entre o governo central e os seus súbditos.

Como estava, então, estruturada a corte de D. Sancho II?

Comecemos pelos ofícios régios. Neste aspecto, a cúria em análise apresenta a mesma composição que as dos reinados anteriores e posteriores. Deste modo, regista-se a existência dos três cargos principais da corte medieval portuguesa: mordomo-mor, alferes-mor e chanceler ${ }^{6}$.

O mordomo, responsável pela administração da casa real, era "o mais elevado oficial e vassalo régio", sendo visto como um vicedominus, um substituto do rei $^{7}$. Competia-lhe a superintendência dos restantes oficiais e tinha algumas funções de âmbito financeiro. Por sua vez, o alferes exercia a função de chefiar o exército, quando o rei não estava presente no campo de batalha, ou de transportar as insígnias régias, caso o monarca participasse nos conflitos. O último destes oficiais mencionado, o chanceler, estava responsável pelo funcionamento de toda a burocracia régia, pois por ele passavam os actos emanados da corte em nome do rei e a ele cumpria apor o sinal de validação nos documentos. Por isso, aparece, praticamente sempre, no final da documentação ${ }^{8}$. É importante

3 Sobre o conceito medieval de corte, veja-se, entre outros, Rita Costa Gomes, A Corte dos Reis de Portugal no Final da Idade Média, Lisboa, Difel, 1995, p. 7-11.

4 José Mattoso, Identificação de um País: Ensaio sobre as origens de Portugal (1096-1325), II - Composição, Lisboa, Editorial Estampa, 1995, p. 97.

5 Georges Duby, "Pouvoir privé, pouvoir public", in Philippe Ariès e Georges Duby (dir.), Histoire de la vie privée, 2. De l'Europe féodale à la Renaissance, Paris, Éditions du Seuil, 1999, p. 30. Cf. Leontina Ventura, A Nobreza de Corte de D. Afonso III, vol. I, Coimbra, Faculdade de Letras, 1992 (dissertação de doutoramento), p. 55.

6 Sobre a existência dos três ofícios-mores na corte portuguesa desde o reinado de D.Afonso Henriques, veja-se Leontina Ventura, A Nobreza de Corte..., vol. I, cit., p. 48-53 e 77-95 e Maria Alegria Marques e João Soalheiro, A Corte dos primeiros reis de Portugal: Afonso Henriques, Sancho I, Afonso II, Gijón, Ediciones Trea, 2009, p. 159-171. Rita Costa Gomes, em A Corte dos Reis de Portugal..., cit., p. 28-37, apresenta as mudanças ocorridas na composição da corte, revelando que, nos séculos XIV-XV, os três ofícios aqui em análise já tinham sido substituídos por outros adaptados aos novos tempos.

7 Leontina Ventura, A Nobreza de Corte..., vol. I, cit., p. 82.

8 Cf. Sandra Virgínia Pereira Gonçalves Bernardino, Sancius Secundus Rex Portugalensis. A Chancelaria de D. Sancho II (1223-1248), Coimbra, 2003 (dissertação de mestrado em História 
salientar que, perante as exigências intelectuais de tais tarefas, o chanceler era recrutado num meio diferente do dos oficiais anteriores. De facto, o saber era o critério responsável pela sua escolha, ao invés do que acontecia com os restantes cargos, em que o sangue desempenhava um papel fundamental. $\mathrm{Na}$ maior parte dos casos, os chanceleres eram clérigos, logo, de um grupo social com preparação intelectual para exercer um cargo que exigia o domínio da língua e da escrita e, até, o saber jurídico ${ }^{9}$. Neste aspecto, o reinado de D. Sancho II não foi excepção.

A ocupação dos cargos de mordomo e de alferes manifesta alguma instabilidade, marcada por uma significativa alternância de indivíduos. Nestas circunstâncias, enquadradas na difícil conjuntura que se viveu durante o governo de D. Sancho, as famílias pertencentes aos dois "partidos" em confronto, o senhorial e o monárquico, foram sucedendo nos ofícios superiores da corte.

Note-se, no entanto, ainda relativamente ao cargo de mordomo que, depois do início da década de 30 do século XIII, este deixou de existir na corte de D. Sancho ${ }^{10}$. Esta alteração poderá apontar para uma tentativa de reestruturação da cúria, sobretudo ao nível dos seus principais ofícios, que se vinha operando desde 1229 e que, no entanto, não teve oportunidade de vingar. Aqui poderemos incluir, enquanto novidade, o aparecimento, em 1235 , do meirinho-mor do reino, provavelmente absorvendo algumas das funções do mordomo, como defende Leontina Ventura ${ }^{11}$.

A partir dos diplomas da chancelaria de D. Sancho II temos ainda conhecimento dos oficiais que estavam ligados à administração do reino, desempenhando funções no âmbito das grandes áreas de governo, como a justiça, e dos que pertenciam à domesticidade do rei, responsáveis por assegurar a manutenção da sua casa.

da Idade Média), p. 163, como exemplo - a partir daqui esta obra será designada apenas por Sancius Secundus...

9 Sobre o recrutamento dos chanceleres em meio eclesiástico durante os reinados anteriores, veja-se Leontina Ventura, A Nobreza de Corte..., vol. I, cit., p. 88-93 e Maria Alegria Marques e João Soalheiro, A Corte dos primeiros reis..., cit., p. 165-167. Para o caso do reinado de D. Afonso III, a primeira autora, nas páginas 93-94, analisa o seu único chanceler, Estêvão Anes, que, ao contrário da maioria, era laico. Terão sido os laços de amizade com o rei que ditaram a sua escolha. No entanto, estes motivos não invalidam que o chanceler possuísse conhecimentos técnicos suficientes para exercer o cargo.

${ }^{10}$ Vejam-se as suas últimas referências em Sancius Secundus..., p. 263 e 267 e Instituto Arquivos Nacionais/Torre do Tombo (Lisboa), Gavetas, Gav. 7, mç. 9, n. ${ }^{\circ} 11$.

${ }^{11}$ Sancius Secundus..., p. 278. Cf. Leontina Ventura, A Nobreza de Corte..., vol. I, cit., p. $96-97$. 
Quanto à administração do reino, para além dos três ofícios-mores, regista-se uma referência a um dapifer (submordomo), em Dezembro de $1224^{12}$. A existência deste cargo poderá indicar que o mordomo de D. Sancho tinha, nesta altura, um oficial subalterno a quem delegava competências.

No plano da justiça surgiram algumas novidades relevantes durante o governo de D. Sancho II. Destaca-se o aparecimento, pela primeira vez de forma inequívoca ${ }^{13}$, em 1235 , de um meirinho-mor do reino, oficial de justiça responsável por controlar os restantes juízes ${ }^{14}$. Depois disto, o cargo somente volta a surgir no reinado de D. Afonso III, em $1261^{15}$, o que demonstra que a intenção de D. Sancho II, de criar um oficial de justiça que superintendesse em todo o reino, não foi bem-sucedida.

Neste reinado, também no âmbito da justiça, se assistiu à consolidação do cargo de sobrejuiz. A este oficial cumpria "julgar questões da competência do tribunal régio", participando mesmo em reuniões plenárias da cúria ${ }^{16}$. Surge na documentação como confirmante, sendo a sua primeira referência, para este reinado, de $1224^{17}$. A partir daqui e até 1248 registam-se quatro sobrejuízes diferentes. Destes destaca-se D. Pedro Martins, que aparece designado como "superjudex totius regni" em dois documentos de 1235 , indicando, assim, a jurisdição destes juízes ${ }^{18}$.

Outra das áreas de governo da cúria corresponde às finanças régias, cujos oficiais asseguravam "a vida material do rei e dos que vivem e se deslocam na sua companhia"19. Na corte de D. Sancho devemos começar por destacar o porteiro-mor, os porteiros e o aparecimento de um porteiro da porta-maior. Ao primeiro

12 Sancius Secundus..., p. 200.

${ }^{13}$ No reinado de D. Afonso Henriques aparece o meirinus palatii, em Maio de 1133. Leontina Ventura coloca a hipótese de ser um meirinho-mor do rei. De qualquer modo, até D. Sancho II, não voltam a surgir referências a este ofício, não nos permitindo afirmar com certeza que se tratava do mesmo cargo. Cf. Leontina Ventura, A Nobreza de Corte..., vol. I, cit., p. 96. José Domingues também analisou a origem e desenvolvimento dos meirinhos-mores no reinado de D. Afonso III, em "Dos Meirinhados às Comarcas Medievais Portuguesas", Initium. Revista Catalana d'Història del Dret, 14 (2009), p. 195-218 e "Os Primórdios do Ius Corrigendi em Portugal: os Meirinhos-Mores de D. Afonso III", Lusíada. Direito, 1 e 2 (2011), p. 175-205.

${ }^{14}$ Existiam outros meirinhos que exerciam a sua jurisdição em áreas administrativas menores. Cf. Leontina Ventura, A Nobreza de Corte..., vol. I, cit., p. 96.

${ }^{15}$ Deste ano data a Lei 57 de Afonso III, que constitui, de certo modo, um regimento do meirinho-mor. Cf. José Mattoso, Identificação de um País..., II, cit., p. 127-128.

${ }^{16}$ Cf. Leontina Ventura, A Nobreza de Corte..., vol. I, cit., p. 120-121.

${ }^{17}$ Cf. Sancius Secundus..., p. 199.

${ }^{18}$ Cf. Ibidem, p. 278 e 280.

${ }^{19}$ Leontina Ventura, A Nobreza de Corte..., vol. I, cit., p. 126. 
competia guardar as portas do paço e da câmara do rei e superintender sobre os outros porteiros, que tinham diversas funções, nomeadamente de carácter fiscal. Na documentação compulsada, a primeira referência a um porteiro data de Dezembro de 1224 e a primeira ao porteiro-mor data de 6 de Junho de $1225^{20}$. Saliente-se que, num documento de Maio de 1229, precisamente o ano em que se registam diversas novidades ao nível da constituição da corte, surge uma distinção entre porteiro-mor do reino e porteiro da porta maior ${ }^{21}$. É provável que estejamos na presença de um porteiro público, do reino, e outro de foro privado, da casa do rei. Começariam, assim, de forma muito lenta, a distinguir-se as funções públicas, ligadas à corte, ao reino, e as funções privadas, ligadas ao monarca e à sua casa.

Embora se conheça apenas um pequeno número de indivíduos que os exerceram, muitos outros ofícios estavam ligados à gestão da casa do rei. Destes, pelo grau de importância, destaca-se o reposteiro-mor, que guardava diversos objectos pessoais do monarca, mas sobretudo o dinheiro que devia ser aplicado nos seus gastos ${ }^{22}$. Por sua vez, o abastecimento alimentar da corte era atribuição dos seguintes oficiais: saquiteiro, responsável pelo pão; eichão ou uchão, que zelava pela despensa; escanção, que tinha a seu cargo o fornecimento de vinho à casa real; e copeiro, encarregado da copa e mesa do rei $^{23}$. Surge ainda referência a dois cevadeiros, a quem cabia o abastecimento da cavalariça real ${ }^{24}$.

De maior proximidade ao monarca e à sua privacidade eram os dois capelães e os dois físicos de que os documentos nos dão conhecimento ${ }^{25}$. O capelão, um dos clérigos da capela do rei, tinha como atribuições assegurar os ofícios do culto para garantir àquele os cuidados da alma. Além disso, era o seu conselheiro pessoal. Por sua vez, o físico era o médico do monarca, garantindo a saúde do seu corpo. Como notou Leontina Ventura, os médicos ou físicos régios estão documentados, pelo menos, desde D. Sancho ${ }^{26}$. No entanto, note-se que, no caso de D. Sancho II, a sua presença nos documentos é rara. De facto,

${ }^{20}$ Cf. Sancius Secundus..., p. 201 e 210, respectivamente.

${ }^{21}$ Cf. Ibidem, p. 267.

${ }^{22} \mathrm{Cf}$., por exemplo, Ibidem, p. 210.

${ }^{23}$ Veja-se, como exemplo, respectivamente para cada um dos cargos, Sancius Secundus..., p. $210,232,247$ e 282 .

${ }^{24}$ Os dois cevadeiros que se conhecem para a corte de D. Sancho são Fernão Gonçalves e Martim Moniz. Cf. Ibidem, p. 232 e 282, respectivamente.

${ }^{25}$ Cf., como exemplo, Ibidem, p. 247 (Pedro Pais, capelão), 362 (Frei Miguel, OP, “abbas regis"), 282 (Mestre Gil, físico) e 301 (Mestre Domingos, físico).

${ }^{26}$ Leontina Ventura, A Nobreza de Corte..., vol. I, cit., p. 140. 
os dois únicos que se conhecem são relativamente tardios, aparecendo apenas nos anos de 1236 e $1237^{27}$.

Mencionemos ainda que os serviços da chancelaria contavam, para além do chanceler, com outros funcionários, de categoria inferior. Nesta corte existem referências aos notários ou escrivães, a quem competia escrever os documentos, tal como é indicado no seu final, tanto através do verbo notare (por exemplo, "Johannes Dominici notuit" ${ }^{28}$ ), como do seu sinónimo scribere (por exemplo, "Dominicus Petriz scripsit" $"$ ").

Como já afirmámos, os ofícios curiais eram ocupados por nobres e eclesiásticos, que também prestavam conselho ao rei, marcando presença nas reuniões onde eram tomadas as decisões. A composição do grupo destes indivíduos dependia de diversos factores, entre os quais as ligações de certas famílias e clérigos ao poder central, que facilitavam a sua entrada no círculo restrito que rodeava o monarca. $\mathrm{O}$ seu conhecimento permite-nos compreender as implicações que a conjuntura político-social do reinado de D. Sancho teve na composição da sua corte.

\section{Os Indivíduos}

Em Junho de 1223, cerca de três meses após a subida de D. Sancho II ao trono, a corte encontrava-se reunida em Montemor-o-Velho para solucionar o conflito entre o poder régio e as infantas, irmãs de D. Afonso $\mathrm{II}^{30}$. Através da completa lista de testemunhas que encerra o diploma temos a percepção da formação da cúria nos inícios do governo em estudo, onde ainda tinham assento todos os principais conselheiros do rei, entre eclesiásticos e barones. Como afirmou Hermenegildo Fernandes, esta é "uma assembleia que parece sem dúvida uma adequada radiografia da balança de poderes entre as facções nos começos do reinado de Sancho"31. De facto, devido à menoridade do rei, encontramos, nesta reunião, membros quer do "partido" monárquico, quer do senhorial, que aproveitaram a conjuntura para regressar à corte.

O rol de testemunhas é encabeçado pelo arcebispo de Braga, ao tempo D. Estêvão Soares da Silva, seguido de um grupo de clérigos, sobretudo dignidades capitulares, mas também, e de grande relevo, o prior dos Pregadores na

\footnotetext{
${ }^{27}$ Cf., supra, n. 25.

${ }^{28}$ Sancius Secundus..., p. 202.

${ }^{29}$ Ibidem, p. 164.

${ }^{30}$ Ibidem, p. 167-172.

${ }^{31}$ Hermenegildo Fernandes, D. Sancho II..., cit., p. 112.
} 
Hispânia, Frei Soeiro Gomes. Acrescente-se, ainda, o peso de Mestre Vicente, deão de Lisboa, e de Mestre Paio Pais, chantre do Porto e prior da colegiada de Santa Maria de Guimarães.

A esta lista de confirmantes eclesiásticos segue-se a dos laicos, pertencentes aos mais altos estratos da rico-homia. Pedro Anes da Nóvoa, mordomo, e Martim Anes de Riba de Vizela, alferes, enquanto oficiais-mores da corte, são os primeiros a ser mencionados. Ambos os indivíduos ocupavam lugar de destaque na entourage régia, não apenas pelas funções exercidas, mas também por pertencerem a famílias do "partido" monárquico, que já apoiavam D. Afonso II. Apesar de confirmar apenas no final do documento, o terceiro oficial-mor da corte, o chanceler, marcou igualmente presença na assembleia. Nesta data, o cargo era ocupado por Gonçalo Mendes Chancinho.

O grande destaque deve, contudo, ser dado aos quatro membros da família de Sousa (Rodrigo, Garcia, Henrique e Vasco Mendes, filhos do conde D. Mendo Gonçalves de Sousa), protagonista do "partido" senhorial, que aproveitaram a menoridade e incapacidade governativa de D. Sancho para retomarem a sua posição na corte régia. Ligado ao mesmo partido e à causa das infantas, estava ainda João Fernandes de Lima, que confirmou imediatamente após o mordomo e o alferes.

Acrescem a este rol outros nomes: Gil Vasques de Soverosa, Abril Peres de Lumiares, Ponço Afonso de Baião, Martim Pais Ribeira, Gomes Mendes de Briteiros, Afonso Peres, Pero Fernandes e Garcia Fernandes Portugal (irmãos). De entre estes, salientam-se os dois primeiros, pelo papel que vieram a desempenhar na corte e nas redes de fidelidade e traição ao monarca ${ }^{32}$.

Traçámos, assim, uma perspectiva global da corte d'O Capelo logo no início do seu reinado. A partir desta data, a composição do principal órgão de governo do reino sofreu significativas alterações no que diz respeito aos indivíduos que nele estavam, fruto, em grande parte, da crise que se vivia. Vejamos, então, essa evolução.

${ }^{32}$ Hermenegildo Fernandes analisa de forma pormenorizada o rol de testemunhas desta carta de composição, traçando mesmo uma breve descrição para cada um dos indivíduos e suas famílias, em D. Sancho II..., cit., p. 112-123. 


\subsection{Nobreza}

\subsubsection{Oficiais-mores}

As consequências da instabilidade político-social da primeira metade do século XIII fizeram sentir-se, sobretudo, nos ofícios-mores da corte. Efectivamente, nos cargos de mordomo e de alferes as mudanças de oficiais foram constantes, dependendo do jogo de forças entre as principais famílias que pretendiam controlar o poder. Os de Sousa e os de Riba de Vizela destacam-se entre aqueles que ocuparam estes lugares cimeiros da cúria.

O primeiro mordomo-mor da corte de D. Sancho foi Pedro Anes da Nóvoa, que transitou do reinado de seu pai. Ter-se-á mantido no cargo, no máximo, até 13 de Setembro de 1223, altura em que surge Martim Anes de Riba de Vizela, que fora antes alferes-mor ${ }^{33}$. Porém, no ano seguinte, o mordomo era já Henrique Mendes, normalmente identificado como de Sousa, que, no final do ano, seria substituído por Gonçalo Mendes de Sousa ${ }^{34}$. O exercício deste ofício pelos dois últimos indivíduos mencionados marca o regresso da família de Sousa à corte no reinado de D. Sancho II, depois de ter sido afastada por D. Afonso II. Gonçalo Mendes foi substituído por João Fernandes de Lima, citado pela primeira vez neste cargo em Janeiro de $1225^{35}$. Em 1226 surgem referências a outros dois mordomos, o que acentua ainda mais a ideia de instabilidade: Abril Peres de Lumiares, que ocupou o cargo antes de 29 de Julho, e Martim Sanches, referido nessa data pela primeira e única vez ${ }^{36}$. Por fim, Pedro Anes da Nóvoa retomou, pelo menos em Janeiro de 1229, o ofício e nele permaneceu até Maio desse ano, inserindo-se, assim, no regresso do "partido" monárquico à corte ${ }^{37}$. Na documentação compulsada, esta é a última referência que temos a este cargo. Apesar de tudo, em Abril de 1231, o mordomo-mor é

${ }^{33}$ Sancius Secundus..., p. 183.

${ }^{34}$ Ibidem, p. 190 e 200.

${ }^{35}$ Ibidem, p. 203. Em Dezembro de 1224, temos conhecimento, através de dois documentos (p. 200 e 201), de um João Fernandes que foi, primeiro, dapiffer e, depois, alferes. Leontina Ventura identifica-o com o de Riba de Vizela e não com o Lima. No entanto, Hermenegildo Fernandes, na relação de oficiais da cúria, considera tratar-se de João Fernandes de Lima, embora com alguma hesitação. Cf. Leontina Ventura, A Nobreza de Corte..., vol. II, cit., p. 989, n. 6 e Hermenegildo Fernandes, D. Sancho II..., cit., p. 352.

${ }^{36}$ Sancius Secundus..., p. 230 e 232.

${ }^{37}$ Ibidem, p. 267. Sobre a possibilidade deste documento datar de 1230 e não de 1229 , veja-se Hermenegildo Fernandes, D. Sancho II..., cit., p. 225-227. 
D. Pascásio, de quem nada sabemos ${ }^{38}$. Perante o desaparecimento deste ofício, Leontina Ventura defende que as suas funções foram absorvidas pelo cargo de meirinho-mor, desempenhado por Pedro Lourenço, de Gundar ou de Riba de Vizela, no ano de $1235^{39}$. Poderemos inserir estas alterações, como bem observou Hermenegildo Fernandes, na crescente burocratização da corte. De facto, esta terá contribuído para o esvaziamento de funções e perda de importância do mordomo, cargo ocupado pelas grandes linhagens do reino, e afirmação de um ofício entregue a um elemento de uma família de segunda linha ${ }^{40}$.

Quanto ao cargo de alferes-mor, este foi ocupado, primeiramente, por Martim Anes de Riba de Vizela, membro de uma das famílias que adquiriram grande predominância na corte no reinado de D. Afonso II ${ }^{41}$. Martim Anes era já alferes no reinado anterior e permaneceu como tal até 1240. Como já vimos, a 13 de Setembro de 1223 surge como mordomo ${ }^{42}$. Uma vez que nesta data não é mencionado qualquer alferes, talvez possamos concluir que acumulasse os dois ofícios ${ }^{43}$. Em 1224, aparecem como alferes, em Abril, Martim de Sousa, que não conseguimos identificar ${ }^{44}$, e, em Dezembro, João Fernandes de Lima $^{45}$. No ano seguinte, e até 1226, encontramos como alferes-mor Fernão Fernandes de Bragança. Depois deste ano, Martim Anes voltou a ocupar o ofício até 1240 , sem interrupções. Devemos salientar que, em alguns intervalos de tempo entre os diversos alferes que foram substituindo Martim Anes, este aparece a desempenhar o cargo ${ }^{46}$. Possivelmente aqueles seriam apenas seus lugares-tenentes.

${ }^{38}$ Instituto Arquivos Nacionais/Torre do Tombo (Lisboa), Gavetas, Gav. 7, mç. 9, n. ${ }^{\circ} 11$. Cf. Leontina Ventura, A Nobreza de Corte..., vol. I, cit., p. 435.

${ }^{39}$ Sancius Secundus..., p. 278 e 280. Cf. Leontina Ventura, A Nobreza de Corte..., vol. I, cit., p. 96-97.

${ }^{40}$ Hermenegildo Fernandes, D. Sancho II..., cit., p. 269.

${ }^{41}$ Cf. José Augusto Pizarro, Linhagens Medievais Portuguesas. Genealogias e Estratégias (1279-1325), vol. I, Porto, Centro de Estudos de Genealogia, Heráldica e História da Família da Universidade Moderna, 1999, p. 535-537.

42 Sancius Secundus..., p. 183.

${ }^{43}$ Hermenegildo Fernandes considera esta mesma hipótese ao colocar, na já mencionada relação de oficiais, a questão da possibilidade de acumulação, em 1223, dos dois cargos, em D. Sancho II..., cit., p. 352.

${ }^{44}$ Cf. Sancius Secundus...,p. 189-190. Este documento é uma tradução portuguesa de Gaspar Rodrigues Fontoura, do ano de 1708. Por isso, a indicação de Martim de Sousa como alferes pode ser uma confusão com Martim Anes [de Riba de Vizela].

${ }^{45}$ Ibidem, p. 201.

${ }^{46}$ Para uma melhor compreensão destas alternâncias, veja-se Hermenegildo Fernandes, D. Sancho II..., cit., p. 352. 
Por último, o ofício de chanceler foi ocupado, durante este reinado, por três indivíduos. O primeiro, pertencente à média nobreza, foi Gonçalo Mendes Chancinho, que ocupava o cargo desde 1212 e que nele se manteve até 29 de Julho de $1226^{47}$. Ao exercer este ofício Gonçalo Mendes contribuiu para a afirmação da sua família durante este reinado ${ }^{48}$.

Sucedeu-lhe Mestre Vicente, a que voltaremos na última parte, depois do qual ocupou o cargo Durão Forjaz, último chanceler deste reinado ${ }^{49}$. Embora esteja apenas documentado desde Julho de 1238, devemos partir do princípio que ocuparia o cargo desde 1236, quando o seu antecessor o abandonou ${ }^{50}$. Personagem pouco conhecida, tudo indica que não possuísse formação académica. Por isso, a sua escolha poderá estar relacionada com a desorganização da chancelaria régia neste período, marcado por forte instabilidade ${ }^{51}$. Todavia, a presença de Durão Forjaz na corte foi muito significativa e não se resumiu ao exercício do seu ofício. De facto, naquela primeira referência de 1238, foi nomeado procurador régio para receber do bispo de Salamanca e deão de Zamora a absolvição do interdito a que D. Sancho estava sujeito, assumindo funções de diplomata, pelo prestígio que gozava junto daquele ${ }^{52}$. Mas a proximidade de Durão Forjaz ao monarca é, sobretudo, evidente na sua presença, em Toledo, a 3 de Janeiro de 1248 , na redacção do testamento d'O Capelo, demonstrando a sua fidelidade ao rei, que por muitos outros foi abandonado no decurso do seu governo ${ }^{53}$.

\subsubsection{Outros Oficiais}

Devido à abundância de ofícios e às escassas referências documentais, far-se-á apenas uma abordagem geral deste grupo, seleccionando os casos mais paradigmáticos.

${ }^{47}$ Sancius Secundus..., p. 232.

${ }^{48}$ Cf. Luís Fernandes Palhares de Vasconcelos, Os Chancinhos: A Corte e a Igreja na Estruturação da Linhagem (Sécs. XII-XIV), Coimbra, 2007 (dissertação de Mestrado em História da Idade Média), p. 24-29.

${ }^{49}$ Optámos por analisar Durão Forjaz neste grupo porque, apesar de desconhecermos as suas origens familiares, não encontrámos qualquer indicação de que tenha professado ordens menores ou maiores. Deste modo, tendo em conta que os oficiais régios eram recrutados, por norma, num dos dois grupos superiores da hierarquia social, é muito provável que este chanceler pertencesse, pelo menos, a uma baixa ou média nobreza.

${ }^{50}$ Sancius Secundus..., p. 305. Cf. Leontina Ventura, A Nobreza de Corte..., vol. II, cit., p. 995, n. 3 .

${ }^{51}$ Cf. José Varandas, «Bonus Rex» ou «Rex Inutilis»..., cit., p. 430-431.

${ }^{52}$ Sancius Secundus..., p. 305.

${ }^{53}$ Ibidem, p. 362. 
$\mathrm{Na}$ esfera da justiça, os sobrejuízes ocupavam um lugar proeminente, não obstante o seu carácter recente. Conhecem-se quatro destes oficiais para o reinado em estudo: Pedro Coronel (1224), Pedro Martins (1229-1236) ${ }^{54}$, Soeiro Gonçalves (1237-1240) e Afonso Martins (1239-1245). A impossibilidade de identificar a origem familiar destes indivíduos aponta para a burocratização que se vinha impondo na corte, desde os anos 20 do século XIII ${ }^{55}$.

Já relativamente à administração da casa, destaca-se o porteiro-mor, cargo que foi exercido por quatro indivíduos, entre 1225 e 1245: Pedro Peres, João Peres castelão, João Qui Venit e Martim Gonçalves, para os quais não existem muitas referências ${ }^{56}$. Devemos destacar aqui, pela relação com o porteiro-mor, o aparecimento de Soeiro Façanha como porteiro da porta maior ${ }^{57}$.

Dos restantes ofícios conhece-se um menor número de indivíduos que os exerceram $^{58}$. Destaque-se apenas, pela sua importância no seio da casa do rei e pela proximidade a este, que o único reposteiro-mor referido é Domingos, escrivão, que terá exercido o cargo, pelo menos, entre 1224 e $1226^{59}$.

\subsubsection{Tenentes}

No século XIII, em geral, e no reinado de D. Sancho II, em particular, as tenências correspondiam a uma das principais circunscrições da administração territorial, sendo, por isso, delegadas pelo monarca aos ricos-homens, que nelas exerciam o poder em seu nome ${ }^{60}$. Pertencentes às grandes linhagens do reino, os tenentes, como eram designados os principes destas terras, tinham

${ }^{54}$ Apesar de termos encontrado referências a Pedro Martins apenas a partir de 1229, para o reinado de D. Sancho II, este indivíduo já ocupava o cargo desde 1222. Neste sentido, coloca-se a dúvida relativamente a Pedro Coronel: "serão uma única pessoa ou tratar-se-á de dois sobrejuízes operando conjuntamente?", citando Leontina Ventura. A documentação não nos permite, neste momento, responder à questão. Cf. Leontina Ventura, A Nobreza de Corte..., vol. II, cit., p. 1039, n. 2. Ainda relativamente a este sobrejuiz, refira-se que é ele que é mencionado, em dois documentos de 1235, como "superjudex totius regni”. Sancius Secundus..., p. 278 e 280.

${ }^{55}$ Cf. Hermenegildo Fernandes, D. Sancho II..., cit., p. 269-270.

${ }^{56}$ Veja-se, como exemplo para cada um deles, respectivamente, Sancius Secundus..., p. 210 , 267,282 e 356.

${ }^{57}$ Ibidem, p. 267.

${ }^{58}$ Veja-se a sua lista completa em Hermenegildo Fernandes, D. Sancho II..., cit., p. 352.

${ }^{59}$ Cf. António Domingues de Sousa Costa, Mestre Silvestre e Mestre Vicente, juristas da contenda entre D. Afonso II e suas irmãs, Braga, Editorial Franciscana, 1963, p. 165 e Sancius Secundus..., p. 232, primeira e última referências, respectivamente.

${ }^{60}$ Para uma síntese sobre as tenências e sua evolução, veja-se Leontina Ventura, "Terras e Julgados", in Joel Serrão e A. H. de Oliveira Marques (dir.), Nova História de Portugal, Maria Helena da Cruz Coelho e Armando Luís de Carvalho Homem (coord.), vol. III, Portugal em 
presença assídua na corte, tendo de prestar conselho e auxílio militar ao rei. De acordo com Leontina Ventura, esta presença justifica-se pelo facto de os ricos-homens exercerem, nas terras que lhes eram confiadas, o poder em nome do soberano e, por isso, estabelecerem o contacto entre o poder central e as circunscrições que governavam ${ }^{61}$.

Designados apenas pelo nome ou por este seguido da terra onde exerciam o cargo $^{62}$, os tenentes confirmavam os diplomas emanados da chancelaria d'O Capelo desde o início do seu governo. As constantes alterações no elenco destes ricos-homens reflectem, claramente, a situação de crise social e política. Com efeito, neste período, as principais linhagens do reino, divididas em "partido" monárquico e senhorial, sucediam-se no poder, procurando sempre recuperar o protagonismo que haviam perdido.

Entre estas famílias, a de Sousa, à cabeça dos que defendiam o poder senhorial, teve sempre um papel de destaque na corte, até ao seu afastamento por D. Afonso II. No entanto, aproveitando a incapacidade governativa de D. Sancho II, os seus membros conseguiram, em momentos-chave deste reinado, retomar o seu lugar, nomeadamente quando o novo soberano ascendeu ao trono. Por esta altura, confirmaram os primeiros documentos emitidos pela chancelaria, designadamente a carta de composição do rei com as suas tias e a concórdia estabelecida com o arcebispo de Braga ${ }^{63}$. No primeiro salienta-se a róbora de Gonçalo Mendes de Sousa, um dos mais tenazes defensores dos direitos das infantas, que veio de Leão apoiar D. Teresa nas lutas contra seu irmão, o rei D. Afonso ${ }^{64}$. Este mesmo rico-homem, em 1224, encontrava-se à frente do mordomado. O seu percurso é exemplificativo da presença e afastamento da corte dos de Sousa, pois já tinha sido mordomo no reinado de D. Sancho I, abandonando o cargo no de D. Afonso II ${ }^{65}$. Após 1226, somente em Março de 1235 se assistiu ao regresso desta família, mais concretamente de Gonçalo Mendes (tenente de Lamego e Viseu), do seu irmão Vasco Mendes (tenente de Bragança) e do seu sobrinho Mem Garcia (tenente de Trasserra), provando

Definição de Fronteiras (1096-1325). Do Condado Portucalense à Crise do Século XIV, Lisboa, Editorial Presença, 1996, p. 542-553.

${ }^{61}$ Cf. Leontina Ventura, A Nobreza de Corte..., vol. I, cit., p. 100.

${ }^{62}$ A primeira lista de confirmantes em que é incluído o nome da terra data de Janeiro de 1229. Cf. Sancius Secundus..., p. 247.

${ }^{63}$ Ibidem, p. 172 e 176.

${ }^{64}$ Cf. Maria Teresa Nobre Veloso, “As Primeiras Medidas...”, cit., p. 96.

${ }^{65}$ Ibidem, p. 200-201. Cf. José Augusto Pizarro, Linhagens Medievais Portuguesas..., vol. I, cit., p. 213-214. 
novo triunfo do "partido" senhorial ${ }^{66}$. Depois da morte dos dois primeiros, em 1236, os únicos de Sousa presentes na corte eram Mem Garcia e seu irmão João Garcia, documentados até 1240, reaparecendo como tenentes de diversas terras no reinado de D. Afonso III, cuja subida ao trono apoiaram ${ }^{67}$.

A linhagem dos de Baião ocupava igualmente um lugar importante entre as famílias mais tradicionais do reino e desde cedo os seus membros acumularam tenências. Na cúria de D. Sancho II, estava apenas representada por Ponço Afonso, que, todavia, confirmou uma quantidade significativa de actos, entre 1223 e $1237^{68}$. Ao longo deste reinado, este membro da família acumulou a jurisdição das tenências da Beira, de Baião e de Bragança, surgindo referido como tenente de duas em simultâneo ou de apenas uma ${ }^{69}$. A coincidência entre o nome da linhagem e o da terra onde eram principes prova que os de Baião estavam na posse de uma tenência familiar, conceito definido pela longa permanência de uma família à frente dessa circunscrição, transmitindo o seu poder hereditariamente ${ }^{70}$. Isto não é, porém, exclusivo dos de Baião. O mesmo se verificou com outras linhagens, como a de Sousa e a de Soverosa.

O "partido" senhorial contava ainda com o apoio de Rodrigo Sanches, bastardo de D. Sancho I, rico-homem, tenente de Entre Douro e Lima (entre 1222 e 1229), da Maia, Vermoim e Lafões (1235) e de Évora (1235-1236) ${ }^{71}$. Documentado para o reinado de D. Sancho II desde 1223, foi, no entanto, em 1235 e 1236, que a sua presença na corte se tornou mais constante ${ }^{72}$. Conotado com a nobreza que se opôs ao poder régio, este aumento de confirmações ter-se-á devido à ascensão do "partido" senhorial, em grande parte protagonizada pelos de Sousa nestes anos. Trata-se de uma figura de relevo por pertencer, por via bastarda, à família real que lhe valeu, na hierarquia das listas de confirmantes laicos, um lugar cimeiro, independentemente da importância das tenências que dominava $^{73}$. Morreu na Lide de Gaia, no Verão de 1245 , onde tomou o partido dos apoiantes de D. Afonso, conde de Bolonha.

\footnotetext{
${ }^{66}$ Sancius Secundus..., p. 278.

${ }^{67}$ Ibidem, p. 334. Sobre o percurso de Mem e João Garcia de Sousa, veja-se Leontina Ventura, A Nobreza de Corte..., vol. II, cit., p. 718-722.

${ }^{68}$ Sancius Secundus..., p. 172 e 297.

${ }^{69}$ Ibidem, p. 247 (tenente de Baião), 263 (tenente de Baião e Beira), 267 (tenente da Beira) e 297 (tenente de Bragança).

${ }^{70}$ Cf. Leontina Ventura, "Terras e Julgados", cit., p. 548.

${ }^{71}$ Cf. Sancius Secundus..., p. 247, 278 e 279, como exemplo, respectivamente.

${ }^{72}$ Para uma melhor percepção da actividade de Rodrigo Sanches na corte, veja-se a Tabela I, em anexo.

${ }^{73}$ Veja-se, por exemplo, o lugar que ocupou na lista de confirmantes da reunião da cúria de Janeiro de 1229, logo depois do mordomo e alferes, em Sancius Secundus..., p. 247.
} 
Os tenentes presentes na corte de D. Sancho II eram ainda escolhidos entre as linhagens que se vinham afirmando nos meandros políticos desde o reinado de D. Afonso II e que integravam o "partido" monárquico, designadamente os de Riba de Vizela, os de Soverosa e os de Tougues ${ }^{74}$. Destaquemos as duas primeiras pela sua importância.

Os de Riba de Vizela, considerados, por José Augusto Pizarro, um exemplo de "história de sucesso", pela sua ascensão ao topo da pirâmide nobiliárquica, ocupavam uma posição central na cúria d' $O$ Capelo e protagonizaram, com os de Sousa, embora em campos opostos, as constantes alterações no elenco governativo ${ }^{75}$. A sua ligação ao monarca prende-se também com questões afectivas, pois a educação do jovem Sancho tinha sido entregue a Martim Fernandes de Riba de Vizela, casado com Estevainha Soares da Silva, irmã do arcebispo de Braga, D. Estêvão. De entre os membros desta família, Martim Anes foi o seu principal representante na corte, tendo sido alferes e mordomo (em 1223, talvez em acumulação com aquele ofício), logo desde o início do reinado.

Além deste indivíduo, o seu irmão,Fernão Anes Cheira, mais esporadicamente, e dois dos seus filhos, Gil e João Martins, sobretudo na fase final do reinado, também eram membros da cúria de D. Sancho II, confirmando diplomas como tenentes. Gil Martins acabou mesmo por se revelar um dos maiores fiéis do rei ao acompanhá-lo até Toledo, aquando do seu exílio, e ao permanecer junto dele até à morte, dado que foi o único rico-homem confirmante do seu último testamento, de 3 de Janeiro de $1248^{76}$.

Embora todos os de Riba de Vizela aqui considerados tenham ocupado tenências, apenas Fernão Anes é citado na documentação como tal, a saber, enquanto governador da terra de Santa Maria e da de Besteiros ${ }^{77}$. No caso dos outros, apenas nos é dado o seu nome, sem menção à circunscrição em que eram tenentes ${ }^{78}$.

Assim como os de Riba de Vizela, os de Soverosa foram das linhagens que mais contribuíram para a afirmação do poder régio durante todo o reinado de D. Sancho II. Na corte em estudo apenas três dos seus membros assistiram

${ }^{74}$ Não obstante o papel da linhagem de Tougues ao lado de D. Sancho II, Soeiro Gomes, tenente de Trasserra e de Lamego, único rico-homem desta família com presença documentada na corte, foi confirmante apenas em dois documentos, um de 1232 e outro de 1237 . Ibidem, p. 274 e 297.

${ }^{75}$ Cf. José Augusto Pizarro, Linhagens Medievais Portuguesas..., vol. I, cit., p. 535-537.

76 Sancius Secundus..., p. 362.

${ }^{77}$ Ibidem, p. 263, 282 e 290.

${ }^{78}$ Cf. José Augusto Pizarro, Linhagens Medievais Portuguesas..., vol. I, cit., p. 544-547. 
a algumas das reuniões curiais a que temos acesso. São eles Gil Vasques de Soverosa e os seus filhos, Martim Gil e Vasco Gil. O primeiro, filho de Vasco Fernandes Cativo, fundador da linhagem, circulava já pela corte desde o reinado de D. Sancho I, quando começou a governar algumas das terras que se manteriam na família, como a tenência de Sousa. A sua primeira referência na documentação de D. Sancho II é de Junho de 1223 e a última data de Maio de $1240^{79}$. Entre 1229 e 1240 , está incluído em quase todas as listas de confirmantes, provavelmente por corresponder a um período tanto de recuperação do poder pelo "partido" monárquico, como de agudização do conflito, em que esta família se opunha à de Sousa. Como rico-homem, Gil Vasques detinha a tenência de algumas terras, entre as quais a de Basto, de Sousa e de Barroso. No entanto, nas confirmações que faz é somente designado como tenente de Sousa (ou apenas pelo nome) ${ }^{80}$. De entre os seus filhos, Martim Gil foi aquele que confirmou um número mais consistente de actos, entre os anos de 1235 e 1239. O seu irmão Vasco Gil apenas assistiu a uma reunião da corte, de Maio de $1238^{81}$. Aquando do exílio de D. Sancho em Toledo, em 1247, ambos os irmãos se terão refugiado em Castela ${ }^{82}$.

Resta apenas enumerar, de forma breve, outras famílias da corte de D. Sancho II que, embora menos assíduas, não deixaram de intervir nas redes sociopolíticas que conduziram à forte instabilidade governativa deste reinado e à Guerra Civil de 1245-1248. Com efeito, estes "outros elementos, conquanto isolados, permitem supor o clima de guerra que se vivia nestes anos" Os exemplos mais significativos correspondem a membros de linhagens que se colocaram ao lado do "partido" senhorial neste período conturbado por manterem relações de vassalidade, sobretudo, com os de Sousa. Salientemos os de Lumiares, os de Briteiros e os de Portocarreiro ${ }^{84}$.

Da primeira família, Abril Peres de Lumiares foi uma das figuras mais marcantes dos acontecimentos políticos que conduziram à deposição do rei. Foi mordomo-mor por um curto espaço de tempo e acumulou diversas tenências na zona da Beira Alta ${ }^{85}$. Colocou-se sempre ao lado dos interesses dos de Sousa,

${ }^{79}$ Sancius Secundus..., p. 172 e 334.

${ }^{80} \mathrm{Cf}$., por exemplo, Ibidem, p. 247.

${ }^{81}$ Ibidem, p. 305, onde confirmam ambos os irmãos.

${ }^{82}$ Cf. José Augusto Pizarro, Linhagens Medievais Portuguesas..., vol. II, cit., p. 208.

${ }^{83}$ Leontina Ventura, A Nobreza de Corte..., vol. I, cit., p. 433.

${ }^{84}$ Para uma lista completa dos ricos-homens, e respectivas famílias, veja-se Tabela I, em anexo.

${ }^{85}$ Sancius Secundus..., p. 230 (mordomo-mor), 247 (tenente de Lamego e Viseu), por exemplo. 
designadamente na questão que opôs D. Afonso II às suas irmãs e na defesa da causa do conde de Bolonha, D. Afonso. Activo participante nas lutas de D. Sancho com o seu irmão, acabou por morrer na Lide de Gaia, em $1245^{86}$.

Dos de Briteiros, os únicos membros que integraram a cúria d'O Capelo foram Gomes Mendes, que dela desapareceu logo em $1223^{87}$, e o seu filho Rui Gomes. Porém, a importância da sua família, sobretudo deste elemento, na conjuntura de meados do século XIII justifica esta breve menção. Com efeito, foi uma das principais linhagens opositoras de D. Sancho e defensores da causa do Bolonhês. A fidelidade de Rui Gomes ao conde foi mesmo premiada com a ascensão à rico-homia e com a sua nomeação como mordomo-mor da corte. Isto não impede que, em Abril de 1245, tenha estado no Porto como confirmante de uma doação de D. Sancho II ao bispo desta cidade. Todavia, poderá ser já um sinal de ligação a D. Afonso, estando aqui em relação com o bispo e não com o rei, a preparar a deposição deste ${ }^{88}$.

Para terminar, os de Portocarreiro tiveram, igualmente, um desempenho muito activo em todo o processo de deposição de D. Sancho e entronização de D. Afonso. Desta família, Pero Anes foi o único a assistir a assembleias da cúria, entre 1237 e $1240^{89}$. Esta associação com os interesses de D. Afonso poderá explicar-se, mais uma vez, pela ligação desta família à de Sousa. Contudo, ao contrário dos de Briteiros, os de Portocarreiro não obtiveram de D. Afonso III qualquer "recompensa"

\subsection{Clero}

O clero de corte ao tempo de D. Sancho II, tal como ao longo de toda a Idade Média portuguesa, marcava presença na cúria através do exercício de ofícios ou da confirmação dos actos, como acontecia, sobretudo, com o alto clero do reino (bispos, abades, priores, mestres).

${ }^{86}$ Sobre Abril Peres de Lumiares, veja-se José Augusto Pizarro, Linhagens Medievais Portuguesas..., vol. I, cit., p. 463-464.

${ }^{87}$ Leontina Ventura e António Resende de Oliveira, "Os Briteiros (séculos XII-XIV). Trajectória social e política”, Revista Portuguesa de História, XXX (1995), p. 75. Cf. Sancius Secundus..., p. 172.

${ }^{88}$ Leontina Ventura, A Nobreza de Corte..., vol. I, cit., p. 83, n. 2. Aqui a autora também se debruça sobre a figura de Rui Gomes e da sua trajectória ascensional. Cf., também, Leontina Ventura e António Resende de Oliveira, “Os Briteiros...”, cit., p. 75-77.

${ }^{89}$ Sancius Secundus..., p. 301, 316 e 334.

${ }^{90}$ Cf. José Augusto Pizarro, Linhagens Medievais Portuguesas..., vol. II, cit., p. 320. 
O cargo de chanceler correspondia a um dos que eram, normalmente, ocupados por eclesiásticos, pelos seus conhecimentos e formação intelectual. No reinado d'O Capelo, o primeiro indivíduo a deter este ofício foi Gonçalo Mendes Chancinho, que já tivemos oportunidade de analisar no grupo da Nobreza. A ele sucedeu, no mesmo mês em que aparece pela última vez, em Julho de 1226, Mestre Vicente, clérigo ${ }^{11}$. No entanto, este já exercia o cargo desde 1224, talvez ainda de uma forma esporádica, como avançam António Domingues de Sousa Costa e Leontina Ventura ${ }^{92}$.

Provavelmente devido à sua nomeação e confirmação como bispo da Guarda, Mestre Vicente abandonou o cargo no início de $1236^{93}$. Este chanceler, jurista graduado em Bolonha, foi uma das figuras mais relevantes do reinado de D. Sancho II, pelo papel político que desempenhou, nomeadamente na defesa da autoridade régia ${ }^{94}$. A ele se pode atribuir a reforma administrativa que se iniciou por volta de 1229 e que foi responsável por alterações estruturantes na corte e governo em estudo. Daqui resultou um processo de burocratização da administração do reino, de que Mestre Vicente foi mesmo protagonista. De facto, com o desaparecimento do cargo de mordomo, normalmente ocupado pelos magnates do reino, o chanceler assumiu a sua importância política, aproveitando para subir na hierarquia do poder. Socorrendo-se da escrita, o seu domínio de acção, o bispo da Guarda, diocese de pequena importância, entre Março de 1235 e Janeiro de 1236, passou a confirmar os documentos logo depois do arcebispo de Braga, principal dignidade eclesiástica do reino ${ }^{95}$.

Além do chanceler, o capelão do rei, pelas suas funções, era também clérigo. Conhecem-se apenas dois para o governo de D. Sancho: Pedro Pais e Frei Miguel. O primeiro esteve à frente da capela régia, pelo menos, entre Janeiro de 1229 e Março de 1235, datas da primeira e última referências ${ }^{96}$. Por sua vez, Frei Miguel, designado como abade do rei (“abbas regis"), confirmou um único documento, o segundo testamento do rei, o que prova que se manteve

${ }^{91}$ Ibidem, p. 237.

${ }^{92}$ Cf. António Domingues de Sousa Costa, Mestre Silvestre ..., cit., p. 165; Leontina Ventura, A Nobreza de Corte..., vol. II, cit., p. 995, n. 2.

93 A última referência como chanceler data de 19 de Janeiro de 1236, Sancius Secundus..., p. 291.

94 A importância do seu papel é reforçada pela incomum validação de dois documentos régios com o sinal rodado do chanceler e não do monarca, como notou Sandra Virgínia Bernardino, em Ibidem, p. 140-141.

${ }_{95}$ Veja-se, como exemplo, Ibidem, p. 278. Cf. Hermenegildo Fernandes, D. Sancho II..., cit., p. 269-270.

${ }_{96}$ Sancius Secundus..., p. 247 e 278. 
fiel ao monarca até ao final da sua vida ${ }^{97}$. Sabemos que era frade mendicante, da Ordem dos Pregadores, demonstrando, a ligação de D. Sancho a estes clérigos, de entre os quais escolheu o seu capelão e confessor ${ }^{98}$.

Os outros eclesiásticos que compunham a corte de D. Sancho tinham por função dar conselho ao rei, integrando as listas de confirmantes dos diplomas. Eram, sobretudo, membros do alto clero, dos quais se destacavam bispos, cónegos, abades e priores de alguns mosteiros e mestres e priores de ordens militares. A composição destas listas esteve, tal como a dos nobres, dependente da difícil conjuntura política e social da primeira metade do século XIII. No entanto, não é tão evidente como na evolução das confirmações laicas. Ainda assim, é possível estabelecer algumas relações, que demonstram a acção do clero neste contexto de crise, nomeadamente no processo de deposição do rei.

Nos primeiros anos do reinado, a presença ou ausência dos bispos, oito no total (arcebispo de Braga, bispos do Porto, Coimbra, Lisboa, Évora, Guarda, Viseu e Lamego), é muito significativa. Num dos primeiros e mais importantes diplomas da chancelaria de D. Sancho II, a carta de composição com as suas tias, para a qual a corte se reuniu na sua quase plenitude, o único prelado confirmante foi D. Estêvão Soares da Silva, arcebispo de Braga. A ele se reuniram, na lista de clérigos, diversas dignidades capitulares de Braga, Coimbra, Lisboa e Porto. Além destes, D. Soeiro Gomes, prior dos Pregadores na Hispânia, também confirmou o acto ${ }^{99}$. Como sabemos, esta composição marcou a divisão dos membros da corte nos dois "partidos", senhorial e monárquico, e a ela não ficaram alheios os eclesiásticos. O mesmo sucedeu com a concórdia estabelecida entre o rei e o arcebispo de Braga, no mesmo mês de Junho de 1223, à qual não esteve presente nenhum bispo, excepto o interveniente. Mais uma vez, marcaram presença o prior dos Pregadores, D. Soeiro Gomes, deões, chantres, tesoureiros de algumas dioceses do reino e um arcediago. Como elementos novos destacam-se o abade de Alcobaça, o mestre do Templo, o prior do Hospital e o abade de S. João de Tarouca ${ }^{100}$.

Até 1229 , período durante o qual as linhagens "senhoriais" tomaram conta do poder, os bispos do reino mantiveram uma presença relativamente constante nas reuniões da cúria, salvo três em que apenas confirmou D. Estêvão,

\footnotetext{
${ }^{97}$ Ibidem, p. 362.

${ }^{98}$ Cf. Hermenegildo Fernandes, D. Sancho II..., cit., p. 22.

${ }^{99}$ Sancius Secundus..., p. 172.

${ }^{100}$ Ibidem, p. 176.
} 
arcebispo de $\mathrm{Braga}^{101}$. A partir deste ano, quando D. Sancho II parece ter tomado efectivamente o poder e o "partido" monárquico regressou à corte, as ausências de prelados tornaram-se mais evidentes e significativas, destacando-se o desaparecimento do arcebispo de Braga e a grande diminuição de confirmações do bispo de Lisboa, D. Soeiro ${ }^{102}$.

De 1229 até 1235 a documentação é escassa, mas a partir deste ano, quando o "partido" senhorial voltou ao poder, as confirmações episcopais reforçaram-se, demonstrando, talvez, uma tendência dos prelados para apoiarem aquela facção. Saliente-se que em 1236 se encontravam na cúria, entre outros, D. Rodrigo Gil, prior do Hospital, e D. Pedro, abade de Alcobaça, que confirmaram todos os diplomas emitidos neste ano. Com o avolumar das tensões, a partir de 1238-1239, e até ao início da Guerra Civil (1245), as reuniões em que participaram eclesiásticos são em número muito reduzido. Com o início da guerra e consequente grande diminuição de actos escritos, os bispos desapareceram das listas de confirmantes ${ }^{103}$.

Uma última nota para o testamento do rei, de Janeiro de 1248, elaborado em Toledo, que nos oferece uma perspectiva dos clérigos que acompanharam o monarca no exílio. É interessante notar que entre os confirmantes deste diploma não se encontra nenhum bispo ou outros membros do alto clero, mas sim frades mendicantes e até priores de igrejas e presbíteros ${ }^{104}$. Leontina Ventura considera curiosa a confirmação de pregadores e franciscanos, por terem sido estes que o papa incumbiu de receber D. Afonso $\mathrm{III}^{105}$. Contudo, Hermenegildo Fernandes atribui esta presença ao apoio que D. Sancho vinha concedendo aos dominicanos, desde os anos 30, e à ligação da família real aos franciscanos, pela acção de Pedro Sanches na trasladação dos mártires de Marrocos ${ }^{106}$.

${ }^{101}$ Ibidem, p. 189, 193 e 237. Note-se que D. Estêvão era irmão de Estevainha Soares, ama do rei. Daí resultou uma ligação próxima entre o arcebispo e o monarca, que permitiu àquele exercer um grande ascendente político sobre este, compreendendo-se a sua presença em todas as reuniões da cúria até 1226, dois anos antes de falecer. Sobre as relações de D. Sancho com o arcebispo de Braga, nem sempre amistosas, veja-se Hermenegildo Fernandes, D. Sancho II..., cit., p. 131-138.

${ }^{102}$ Um grande exemplo desta mudança é a reunião da cúria de Janeiro de 1229, no Palácio de Coimbra, em presença do cardeal D. João de Abbeville, legado apostólico, à qual não compareceram nem o arcebispo de Braga nem o bispo de Lisboa. Ibidem, p. 246-247.

${ }^{103}$ Para uma melhor compreensão destas flutuações, veja-se Tabela II, em anexo.

${ }^{104}$ Sancius Secundus..., p. 362-363.

${ }^{105}$ Leontina Ventura, “A Crise de Meados do Século XIII”, cit., p. 121, n. 137.

${ }^{106}$ Hermenegildo Fernandes, D. Sancho II..., cit., p. 22. 
Nos principais bispos do reino o monarca encontrou o seu “'inimigo' mais irredutível" 107 . Não obstante o facto de as difíceis relações entre aquele e alguns prelados se terem iniciado nos primeiros anos do reinado, foi, sobretudo, a partir dos anos 40 do século XIII que elas se tornaram mais intensas. De facto, alguns destes eclesiásticos, concedendo o seu apoio a D. Afonso, conde de Bolonha, foram responsáveis pela preparação da deposição de D. Sancho junto do papa. Entre eles contavam-se o arcebispo de Braga, num primeiro momento, D. Silvestre Godinho, depois substituído por D. João Viegas de Portocarreiro, o bispo do Porto, D. Pedro Salvadores, o de Coimbra, D. Tibúrcio, e o de Lisboa, D. Aires Vasques. Quase todos, à excepção de D. João Viegas e D. Aires Vasques, que ainda não eram arcebispo e bispo, respectivamente, chegaram a confirmar documentos régios, antes de $1245^{108}$.

Em 1244, D. Silvestre Godinho encontrava-se na cúria pontifícia, dando início ao processo de afastamento do rei. No entanto, morto ainda nesse ano, coube ao seu sucessor, D. João Viegas, um dos membros da família de Portocarreiro que se opôs ao rei, levar avante a ideia concebida por seu antecessor. No ano seguinte, tanto este arcebispo como os bispos acima citados marcaram presença no concílio de Lião, que terá oferecido ao futuro poder do conde de Bolonha "um vasto enquadramento e uma segura legitimidade" O rei terá ainda tentado contrariar a actuação dos prelados, ao fazer duas doações ao bispo do Porto, em Abril de $1245^{110}$, provavelmente com o intuito de o aliciar a impedir a sua deposição. Todavia, D. Sancho não foi bem-sucedido, ou por impossibilidade de D. Pedro para atender ao seu pedido ou por simplesmente não o querer fazer ${ }^{111}$.

A acção diplomática dos bispos, na cúria pontifícia, resultou na promulgação, por Inocêncio IV, da bula de deposição Grandi non immerito, de 24 de Julho de 1245, que afastou D. Sancho II do poder, declarando-o "rex inutilis" 12.

\footnotetext{
${ }^{107}$ José Varandas, «Bonus Rex» ou «Rex Inutilis»..., cit., p. 487.

${ }^{108} \mathrm{Cf}$. Tabela II, em anexo.

${ }^{109}$ Leontina Ventura, D. Afonso III, Lisboa, Temas e Debates, 2009, p. 83.

${ }^{110}$ Sancius Secundus..., p. 355-356 e 359.

${ }^{111}$ Cf. Leontina Ventura, D. Afonso III, cit., p. 85.

${ }^{112}$ António Domingues de Sousa Costa, Mestre Silvestre..., cit., p. 436-439, n. 547. Cf. Leontina Ventura, D. Afonso III, cit., p. 83-86, onde a autora descreve, de forma concisa e clara, a presença dos bispos em Roma.
} 


\section{Conclusão}

A corte de D. Sancho II, nosso objecto de análise, apresenta, como pudemos constatar, a estrutura que caracterizou as restantes cúrias régias portuguesas medievais. No entanto, esta torna-se um caso único, pois a situação de crise que marcou todo o reinado d' $O$ Capelo muito influenciou a sua composição, ao nível dos ofícios e dos indivíduos que rodeavam o monarca, ao qual prestavam auxilium e consilium.

À semelhança das cortes dos reinados anteriores, nomeadamente a de D. Afonso II, que a precedeu, a de D. Sancho II manteve a estrutura deste órgão do poder, nomeadamente no que respeita aos três ofícios superiores: mordomo, alferes e chanceler. No entanto, a partir dos anos 30 do século XIII, fruto do processo de burocratização da corte operado a partir de 1229, a cúria por nós estudada apresenta já algumas novidades. Destaca-se o desaparecimento do mordomo e o surgimento de um novo ofício, o de meirinho-mor, que poderá ter assumido algumas das atribuições daquele. Muitas outras foram as reformas que se tentaram empreender mas que, em contexto de crise, como vimos, não vingaram.

Em relação às listas de confirmantes laicos e eclesiásticos das reuniões da cúria, estas estiveram dependentes da instabilidade do momento e da sua consequente divisão nos "partidos" senhorial e monárquico. Nestas circunstâncias, linhagens como a de Sousa e a de Riba de Vizela desempenharam um papel fundamental, alternando no poder, entre os anos de 1223 e 1245, quando, devido à Guerra Civil, a corte se alterou profundamente. Por sua vez, os clérigos da cúria de D. Sancho, cuja presença teve mutações menos evidentes que a dos laicos, destacaram-se sobretudo pelas relações, muitas vezes de conflito, que mantiveram com o rei. Alguns deles, através da sua diplomacia, foram mesmo os grandes responsáveis pela promulgação da bula de deposição d'O Capelo.

Em conclusão, a corte de D. Sancho II foi de tal forma afectada pelas circunstâncias de crise que uma comparação entre a sua composição na fase final deste reinado e na que antecedeu o período de maior convulsão revela "os estragos que os anos de conflito e o seu [do rei] prestígio devastado haviam provocado no brilho da entourage real" 113 .

${ }^{113}$ Hermenegildo Fernandes, D. Sancho II..., cit., p. 22. 


\section{Anexo}

Tabela I - Protagonismo dos ricos-homens na Cúria (confirmantes nos diplomas de Sancho II)

\begin{tabular}{|c|c|c|c|c|c|c|c|c|c|c|c|c|c|c|c|c|c|c|c|c|c|c|c|c|}
\hline N. ${ }^{\circ}$ Regesta & & 1 & 2 & 3 & 7 & 10 & 11 & 12 & 13 & 16 & 17 & 19 & 20 & 21 & 22 & 24 & 26 & 30 & 33 & 33 & 34 & 35 & 39 & 40 \\
\hline Ano & & 23 & 23 & 23 & 23 & 23 & 24 & 24 & 24 & 24 & 24 & 24 & 24 & 24 & 25 & 25 & 25 & 26 & 26 & 26 & 26 & 26 & 29 & 29 \\
\hline \multirow[t]{3}{*}{ Família Real } & Martim Sanches & & $*$ & & & & & & & & & & & & & & & & & & $*$ & & & \\
\hline & Rodrigo Sanches & & & & * & & & & & & & & & & * & & & & & & & & * & * \\
\hline & Fernando de Serpa & & & & & & & & & & & & & & & & & & & & & & & \\
\hline \multirow[t]{8}{*}{ Sousa } & Gonçalo Mendes & * & $*$ & * & & & * & & * & & * & * & * & * & & & * & & * & * & * & & & \\
\hline & Rodrigo Mendes & * & $*$ & * & * & * & * & * & & & & & & & & & & & & & & & & \\
\hline & Garcia Mendes & * & $*$ & * & & & $*$ & & & & * & & & & & & & & & & & & & \\
\hline & Henrique Mendes & * & * & * & & & $*$ & & $*$ & & $*$ & & & & & & & & & & & & & \\
\hline & Vasco Mendes & & $*$ & & & * & & & & $*$ & $*$ & & $*$ & $*$ & & & & & & & & & & \\
\hline & Mendo Gonçalves & & $*$ & & & & & & & & & & * & * & & * & & & & & & & & \\
\hline & Mem Garcia & & & & & & & & & & & & & & & & & & & & & & & \\
\hline & João Garcia & & & & & & & & & & & & & & & & & & & & & & & \\
\hline$?$ & Fernăo Garcia & & & & & & & & & & & & & & & & & & & & * & & & \\
\hline \multirow[t]{2}{*}{ Bragança } & Fernão Fernandes & & & & & & $*$ & & & & & $*$ & & * & * & * & & * & $*$ & * & & & * & \\
\hline & Pedro Garcia & & & & & & & & & & & & & * & * & * & & & & & & & & \\
\hline Maia & João Peres & * & $*$ & & & & 。 & & & & & & $*$ & & * & * & & & $*$ & $*$ & & & & \\
\hline Baiāo & Ponço Afonso & & * & * & * & * & & & * & & . & & $*$ & * & * & * & & & * & * & * & & * & * \\
\hline Lumiares & Abril Peres & & $*$ & $*$ & $*$ & & & & & & 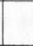 & & $*$ & $*$ & * & 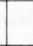 & & & $*$ & $*$ & $*$ & & * & * \\
\hline \multirow[t]{4}{*}{ Riba de Vizela } & Martim Anes & * & $*$ & $*$ & * & $*$ & $*$ & & $*$ & & $*$ & & & & * & $*$ & * & & $*$ & $*$ & $*$ & * & * & * \\
\hline & Fernāo Anes & & & * & & & & & & & & & & & & * & * & & & & & & & \\
\hline & Joäo Martins & & & & & & & & & & & & & & & & & & & & & & & \\
\hline & Gil Martins & & & & & & & & & & & & & & & & & & & & & & & \\
\hline \multirow[t]{3}{*}{ Soverosa } & Gil Vasques & & $*$ & $*$ & & & $*$ & & & & * & $*$ & & & & * & * & & * & * & * & & * & \\
\hline & Martim Gil & & & & & & & & & & & & & & & & & & & & & & & \\
\hline & Vasco Gil & & & & & & & & & & & & & & & & & & & & & & & \\
\hline Nóvoa & Pero Anes & $*$ & * & $*$ & & & & & & & & & & & & & & & & & & & * & * \\
\hline Lima & João Fernandes & * & * & * & & & * & & * & & & * & * & * & * & * & & & & & & * & & \\
\hline Ribeira & Martim Pais & & * & & & & & & & & & & & & & & & & & & * & & * & \\
\hline Valadares & Soeiro Peres & & & & & & & & & & & & & & & & & & $*$ & * & & & * & * \\
\hline Tougues & Soeiro Gomes & & & & & & & & & & & & & & & & & & & & & & & \\
\hline Redondo & Joăo Peres & & & & & & & & & & & & & & & & & & & & & & & \\
\hline Briteiros & Gomes Mendes & & $*$ & & & & & & & & & & & & & & & & & & & & & \\
\hline Portocarreiro & Pero Anes & & & & & & & & & & & & & & & & & & & & & & & \\
\hline Novais & Pero Pais & & & & & & & & & & & & & & & & & & & & & & & \\
\hline Belmir & Estêvão Soares & & & & & & & & & & & & & & & & & & & & & & & * \\
\hline Gundar & Pedro Lourenço & & & & & & & & & & & & & & & & & & & & & & & \\
\hline
\end{tabular}




\begin{tabular}{|c|c|c|c|c|c|c|c|c|c|c|c|c|c|c|c|c|c|c|c|c|c|c|}
\hline N. ${ }^{\circ}$ Regesta & & 41 & 42 & \begin{tabular}{|l|l|l}
43 & 4 \\
\end{tabular} & \begin{tabular}{l|l}
44 & 4
\end{tabular} & $46 \quad 4$ & 4950 & \begin{tabular}{l|l|}
0 & 51
\end{tabular} & 52 & 535 & 545 & \begin{tabular}{|l|l}
565 \\
58
\end{tabular} & \begin{tabular}{l|l}
8 & 5 \\
\end{tabular} & $\begin{array}{ll}9 & 60\end{array}$ & $\begin{array}{ll}067 \\
67\end{array}$ & $\begin{array}{ll}768 \\
\end{array}$ & \begin{tabular}{|l|l}
8 & 7
\end{tabular} & 377 & 784 & 85 & 868 & 87 \\
\hline Ano & & 29 & 29 & 2928 & \begin{tabular}{l|l}
281 & 39 \\
29 & 3
\end{tabular} & 323 & $35 \quad 35$ & 536 & 36 & 36 & \begin{tabular}{l|l}
36 & 3 \\
\end{tabular} & 363 & 73 & 738 & 835 & 39 & 940 & 4 & 45 & 45 & 46 & 48 \\
\hline \multirow[t]{3}{*}{ Família Real } & Martim Sanches & & & & & & & & & & & & & & & & & & & & & \\
\hline & Rodrigo Sanches & * & * & & & & $*$ * & \begin{tabular}{l|l|}
$*$ & $*$ \\
\end{tabular} & * & * & * $*$ * & * & & & * & * & * & & & & & \\
\hline & Fernando de Serpa & & & & & & & & & & & & * & & & & & & & & & \\
\hline \multirow[t]{9}{*}{ Sousa } & Gonçalo Mendes & & & & & & * $*$ & \begin{tabular}{l|l|}
$*$ & $*$ \\
\end{tabular} & * & * & * $\quad *$ & * & & & & & & & & & & \\
\hline & Rodrigo Mendes & & & & & & & & & & & & & & & & & & & & & \\
\hline & Garcia Mendes & & & & & & & & & & & & & & & & & & & & & \\
\hline & Henrique Mendes & & & & & & & & & & & & & & & & & & & & & \\
\hline & Vasco Mendes & & & & & & * $*$ * & * $* *$ & * & * & * $\quad *$ & * & & & & & & & & & & \\
\hline & Mendo Gonçalves & & & & & & & & & & & & & & & & & & & & & \\
\hline & Mem Garcia & & & & & & \begin{tabular}{l|l}
$*$ & $*$ \\
\end{tabular} & \begin{tabular}{l|l|}
$*$ & $*$ \\
\end{tabular} & * & * & * $\quad$ * & * * & & & * & * & * & & & & & \\
\hline & João Garcia & & & & & & & & & & & & & & * & * & $*$ & & & & & \\
\hline & Fernão Garcia & & & & & & & & & & & & & & & & & & & & & \\
\hline \multirow[t]{2}{*}{ Bragança } & Fernāo Fernandes & * & $*$ & * & $*$ & $*$ & & & & & & & & & & & & & & & & \\
\hline & Pedro Garcia & & & & & & & & & & & & & & & & & & & & & \\
\hline Maia & João Peres & & & & & & & & & & & & & & & & & & & & * & \\
\hline Baiáo & Ponço Afonso & * & $*$ & $*$ & * & & * $*$ & * & & & & * & & & & & & & & & & \\
\hline Lumiares & Abril Peres & $*$ & $*$ & & * & & . & . & & & & & & & * & * & * & * & & & & \\
\hline \multirow[t]{4}{*}{ Riba de Vizela } & Martim Anes & * & $*$ & * & * * & $* *$ & * $*$ & $* \mid *$ & $*$ & * & * * & * * & * & : & $*$ & * & * & & & & & \\
\hline & Fernão Anes & & * & & & & & $*$ & & * & & & & & & & & & & & & \\
\hline & Joāo Martins & & & & & & & & & & & & & & * & $*$ & : $*$ & & & & & \\
\hline & Gil Martins & & & & & & & & & & & & & & & & & & & & * & * \\
\hline \multirow[t]{3}{*}{ Soverosa } & Gil Vasques & * & $*$ & * & * , & * * & * $*$ * & * $*$ & $*$ & $*$ & * * & * $*$ & & * & $*$ & $*$ & $=*$ & & & & & \\
\hline & Martim Gil & & & & & $*$ & * $*$ & * $*$ & * & * & * * & * $*$ & * * & * & * & * & & & & & & \\
\hline & Vasco Gil & & & & & & & & & & & & & * & & & & & & & & \\
\hline Nóvoa & Pero Anes & $*$ & $*$ & * & * & * & * $*$ * & & & * & * * & $*$ & & & & & & & & & & \\
\hline Lima & Joāo Fernandes & & & & & & & & & & & & & & & & & & & & & \\
\hline Ribeira & Martim Pais & * & & & & * & * & * & & & & & & & & & & & & & & \\
\hline Valadares & Soeiro Peres & $*$ & * & & * & & & & & & & & & & & & & & & & & \\
\hline Tougues & Soeiro Gomes & & & & & $*$ & & & & & & * & & & & & & & & & & \\
\hline Redondo & Joäo Peres & & & & & & & & & & & & & & * & $*$ & * & & & & & \\
\hline Briteiros & Gomes Mendes & & & & & & & & & & & & & & & & & & & & & \\
\hline Portocarreiro & Pero Anes & & & & & & & & & & & & * & & * & & $*$ & 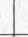 & & & & \\
\hline Novais & Pero Pais & * & & $*$ & $*$ & & & & & & & & & & & & & & & & & \\
\hline Belmir & Estêvão Soares & * & * & & $*$ & $*$ & & & & & & * & * & * & & * & : & & & & & \\
\hline Gundar & Pedro Lourenço & & & & & & & $*$ & $*$ & * & & & & & & & & & & & & \\
\hline
\end{tabular}

Nota: Embora surgindo sem apelido nas listas de confirmantes, como era uso nesta época em que ele ainda nāo começara a fazer parte do nome, a esmagadora maioria dos confirmantes estáo identificados com segurança, sobretudo desde os trabalhos dos discípulos de José Mattoso que prosseguiram os seus estudos sobre a nobreza (Leontina Ventura, José Augusto Pizarro, António Resende de Oliveira). Num caso porém, devidamente marcado com?, náo consegui resolver de forma inteiramente convincente a homonímia entre um Sousa e un Bragançāo, Fernāo Garcia. O facto de no mesmo diploma confirmar também o chefe da primeira linhagem. Gonçalo Mendes, mas nenhum membro da segunda, e sobretudo o de por esse tempo o Sousão ser tenente de Gouveia, enquanto o Braganção não tem qualquer tenência atestada, pareceram-me fundamento suficiente para a opção feita. Anotaria ainda que a ordenação das linhagens segue o critério de grupos de importância e, entre eles, uma ordem descendente.

Fonte: Hermenegildo Fernandes, D. Sancho II..., cit., p. 354-355. 
Tabela II - Bispos confirmantes dos documentos da chancelaria de D. Sancho II ${ }^{114}$

\begin{tabular}{|c|c|c|c|c|c|c|c|c|c|}
\hline \multirow[b]{2}{*}{ Doc. } & \multirow[b]{2}{*}{ Ano } & \multicolumn{8}{|c|}{ Bispos } \\
\hline & & $\begin{array}{c}\text { Arcebispo } \\
\text { de Braga }\end{array}$ & $\begin{array}{c}\text { Bispo do } \\
\text { Porto }\end{array}$ & $\begin{array}{l}\text { Bispo de } \\
\text { Coimbra }\end{array}$ & $\begin{array}{c}\text { Bispo de } \\
\text { Lisboa }\end{array}$ & $\begin{array}{c}\text { Bispo de } \\
\text { Évora }\end{array}$ & $\begin{array}{l}\text { Bispo de } \\
\text { Lamego }\end{array}$ & $\begin{array}{c}\text { Bispo da } \\
\text { Guarda }\end{array}$ & $\begin{array}{c}\text { Bispo de } \\
\text { Viseu }\end{array}$ \\
\hline 1 & 1223 & \begin{tabular}{|c} 
D. Estêvão \\
Soares da \\
Silva
\end{tabular} & $\begin{array}{c}\text { D. Martinho } \\
\text { Rodrigues }\end{array}$ & $\begin{array}{c}\text { D. Pedro } \\
\text { Soares }\end{array}$ & $\begin{array}{c}\text { D. Soeiro } \\
\text { Viegas }\end{array}$ & D. Soeiro & D. Paio & D. Martinho & $\begin{array}{l}\text { D. Gil } \\
\text { (eleito) }\end{array}$ \\
\hline 2 & 1223 & $\begin{array}{c}\text { D. Estêvão } \\
\text { Soares da } \\
\text { Silva }\end{array}$ & - & - & - & - & - & - & - \\
\hline 3 & 1223 & - & - & - & - & - & - & - & - \\
\hline 7 & 1223 & \begin{tabular}{|c} 
D. Estêvão \\
Soares da \\
Silva
\end{tabular} & \begin{tabular}{|c|} 
D. Martinho \\
Rodrigues
\end{tabular} & $\begin{array}{c}\text { D. Pedro } \\
\text { Soares }\end{array}$ & - & - & D. Paio & - & D. Gil \\
\hline 11 & 1224 & $\begin{array}{c}\text { D. Estêvão } \\
\text { Soares da } \\
\text { Silva }\end{array}$ & $\begin{array}{c}\text { D. Martinho } \\
\text { Rodrigues }\end{array}$ & $\begin{array}{c}\text { D. Pedro } \\
\text { Soares }\end{array}$ & $\begin{array}{c}\text { D. Soeiro } \\
\text { Viegas }\end{array}$ & D. Soeiro & D. Paio & D. Martinho & $\begin{array}{l}\text { D. Gil } \\
\text { (eleito) }\end{array}$ \\
\hline 12 & 1224 & \begin{tabular}{|c} 
D. Estêvão \\
Soares da \\
Silva
\end{tabular} & - & - & - & - & - & - & - \\
\hline 13 & 1224 & \begin{tabular}{|c} 
D. Estêvão \\
Soares da \\
Silva
\end{tabular} & $\begin{array}{c}\text { D. Martinho } \\
\text { Rodrigues }\end{array}$ & $\begin{array}{c}\text { D. Pedro } \\
\text { Soares }\end{array}$ & $\begin{array}{c}\text { D. Soeiro } \\
\text { Viegas }\end{array}$ & D. Soeiro & D. Paio & D. Martinho & D. Gil \\
\hline 16 & 1224 & $\begin{array}{c}\text { D. Estêvão } \\
\text { Soares da } \\
\text { Silva }\end{array}$ & - & - & - & - & - & - & - \\
\hline 17 & 1224 & \begin{tabular}{|c} 
D. Estêvão \\
Soares da \\
Silva
\end{tabular} & $\begin{array}{c}\text { D. Martinho } \\
\text { Rodrigues }\end{array}$ & - & - & - & D. Paio & - & - \\
\hline 20 & 1224 & $\begin{array}{c}\text { D. Estêvão } \\
\text { Soares da } \\
\text { Silva }\end{array}$ & \begin{tabular}{|c|} 
D. Martinho \\
Rodrigues
\end{tabular} & $\begin{array}{c}\text { D. Pedro } \\
\text { Soares }\end{array}$ & $\begin{array}{c}\text { D. Soeiro } \\
\text { Viegas }\end{array}$ & D. Soeiro & D. Paio & D. Martinho & $\begin{array}{l}\text { D. Gil } \\
\text { (eleito) }\end{array}$ \\
\hline 21 & 1224 & $\begin{array}{c}\text { D. Estêvão } \\
\text { Soares da } \\
\text { Silva }\end{array}$ & $\begin{array}{c}\text { D. Martinho } \\
\text { Rodrigues }\end{array}$ & $\begin{array}{c}\text { D. Pedro } \\
\text { Soares }\end{array}$ & $\begin{array}{c}\text { D. Soeiro } \\
\text { Viegas }\end{array}$ & D. Soeiro & D. Paio & D. Martinho & D. Gil \\
\hline 22 & 1225 & \begin{tabular}{|c} 
D. Estêvão \\
Soares da \\
Silva
\end{tabular} & \begin{tabular}{|c|} 
D. Martinho \\
Rodrigues
\end{tabular} & $\begin{array}{c}\text { D. Pedro } \\
\text { Soares }\end{array}$ & $\begin{array}{c}\text { D. Soeiro } \\
\text { Viegas }\end{array}$ & D. Soeiro & - & D. Martinho & D. Gil \\
\hline
\end{tabular}

${ }^{114}$ Os números dos documentos aqui apresentados referem-se aos dos diplomas publicados na obra Sancius Secundus... 


\begin{tabular}{|c|c|c|c|c|c|c|c|c|c|}
\hline \multirow[b]{2}{*}{ Doc. } & \multirow[b]{2}{*}{ Ano } & \multicolumn{8}{|c|}{ Bispos } \\
\hline & & $\begin{array}{c}\text { Arcebispo } \\
\text { de Braga }\end{array}$ & $\begin{array}{c}\text { Bispo do } \\
\text { Porto }\end{array}$ & $\begin{array}{l}\text { Bispo de } \\
\text { Coimbra }\end{array}$ & $\begin{array}{c}\text { Bispo de } \\
\text { Lisboa }\end{array}$ & $\begin{array}{l}\text { Bispo de } \\
\text { Évora }\end{array}$ & $\begin{array}{l}\text { Bispo de } \\
\text { Lamego }\end{array}$ & $\begin{array}{c}\text { Bispo da } \\
\text { Guarda }\end{array}$ & $\begin{array}{c}\text { Bispo de } \\
\text { Viseu }\end{array}$ \\
\hline 24 & 1225 & \begin{tabular}{|c|} 
D. Estêvão \\
Soares da \\
Silva \\
\end{tabular} & $\begin{array}{c}\text { D. Martinho } \\
\text { Rodrigues }\end{array}$ & $\begin{array}{c}\text { D. Pedro } \\
\text { Soares }\end{array}$ & $\begin{array}{c}\text { D. Soeiro } \\
\text { Viegas }\end{array}$ & D. Soeiro & D. Paio & D. Martinho & D. Gil \\
\hline 33 & 1226 & \begin{tabular}{|c|} 
D. Estêvão \\
Soares da \\
Silva
\end{tabular} & $\begin{array}{c}\text { D. Martinho } \\
\text { Rodrigues }\end{array}$ & $\begin{array}{c}\text { D. Pedro } \\
\text { Soares }\end{array}$ & $\begin{array}{c}\text { D. Soeiro } \\
\text { Viegas }\end{array}$ & D. Soeiro & D. Paio & D. Martinho & D. Gil \\
\hline [33a] & 1226 & \begin{tabular}{|c|} 
D. Estêvão \\
Soares da \\
Silva \\
\end{tabular} & $\begin{array}{c}\text { D. Martinho } \\
\text { Rodrigues }\end{array}$ & $\begin{array}{l}\text { D. Pedro } \\
\text { Soares }\end{array}$ & $\begin{array}{c}\text { D. Soeiro } \\
\text { Viegas }\end{array}$ & D. Soeiro & D. Paio & - & D. Gil \\
\hline 34 & 1226 & \begin{tabular}{|c|} 
D. Estêvão \\
Soares da \\
Silva
\end{tabular} & $\begin{array}{c}\text { D. Martinho } \\
\text { Rodrigues }\end{array}$ & $\begin{array}{l}\text { D. Pedro } \\
\text { Soares }\end{array}$ & $\begin{array}{c}\text { D. Soeiro } \\
\text { Viegas }\end{array}$ & D. Soeiro & D. Paio & - & D. Gil \\
\hline 35 & 1226 & \begin{tabular}{|c|} 
D. Estêvão \\
Soares da \\
Silva \\
\end{tabular} & - & - & - & - & - & - & - \\
\hline 39 & 1229 & - & $\begin{array}{c}\text { D. Martinho } \\
\text { Rodrigues }\end{array}$ & $\begin{array}{c}\text { D. Pedro } \\
\text { Soares }\end{array}$ & - & D. Soeiro & D. Paio & - & D. Gil \\
\hline 40 & 1229 & - & $\begin{array}{c}\text { D. Martinho } \\
\text { Rodrigues }\end{array}$ & $\begin{array}{c}\text { D. Pedro } \\
\text { Soares }\end{array}$ & $\begin{array}{c}\text { D. Soeiro } \\
\text { Viegas }\end{array}$ & - & D. Paio & - & D. Gil \\
\hline 41 & 1229 & - & - & $\begin{array}{l}\text { D. Pedro } \\
\text { Soares }\end{array}$ & - & D. Soeiro & D. Paio & - & D. Gil \\
\hline 42 & 1229 & - & $\begin{array}{c}\text { D. Martinho } \\
\text { Rodrigues }\end{array}$ & $\begin{array}{c}\text { D. Pedro } \\
\text { Soares }\end{array}$ & - & D. Soeiro & D. Paio & - & D. Gil \\
\hline 43 & 1229 & - & - & - & - & D. Soeiro & - & $\begin{array}{c}\text { D. Vicente } \\
\text { (eleito) }\end{array}$ & - \\
\hline 46 & 1232 & - & $\begin{array}{c}\text { D. Martinho } \\
\text { Rodrigues }\end{array}$ & $\begin{array}{c}\text { D. Pedro } \\
\text { Soares }\end{array}$ & $\begin{array}{c}\text { D. Soeiro } \\
\text { Viegas }\end{array}$ & D. Soeiro & D. Paio & $\begin{array}{c}\text { D. Vicente } \\
\text { (eleito) }\end{array}$ & D. Gil \\
\hline 49 & 1235 & $\begin{array}{c}\text { D. Silvestre } \\
\text { Godinho }\end{array}$ & - & $\begin{array}{c}\text { D. Tibúrcio } \\
\text { (eleito) }\end{array}$ & - & D. Fernando & D. Paio & $\begin{array}{c}\text { D. Vicente } \\
\text { (eleito) }\end{array}$ & D. Gil \\
\hline 50 & 1235 & $\begin{array}{c}\text { D. Silvestre } \\
\text { Godinho }\end{array}$ & - & $\begin{array}{c}\text { D. Tibúrcio } \\
\text { (eleito) }\end{array}$ & - & D. Fernando & D. Paio & D. Vicente & D. Gil \\
\hline 51 & 1236 & $\begin{array}{c}\text { D. Silvestre } \\
\text { Godinho }\end{array}$ & $\begin{array}{c}\text { D. Pedro } \\
\text { Salvadores }\end{array}$ & $\begin{array}{c}\text { D. Tibúrcio } \\
\text { (eleito) }\end{array}$ & - & D. Fernando & D. Paio & D. Vicente & D. Gil \\
\hline 52 & 1236 & $\begin{array}{c}\text { D. Silvestre } \\
\text { Godinho }\end{array}$ & - & - & - & D. Fernando & D. Paio & D. Vicente & D. Gil \\
\hline 53 & 1236 & $\begin{array}{c}\text { D. Silvestre } \\
\text { Godinho }\end{array}$ & - & - & - & D. Fernando & D. Paio & - & D. Gil \\
\hline 54 & 1236 & $\begin{array}{c}\text { D. Silvestre } \\
\text { Godinho }\end{array}$ & - & - & - & D. Fernando & D. Paio & - & D. Gil \\
\hline 56 & 1236 & $\begin{array}{c}\text { D. Silvestre } \\
\text { Godinho }\end{array}$ & - & - & - & D. Fernando & D. Paio & - & D. Gil \\
\hline
\end{tabular}




\begin{tabular}{|c|c|c|c|c|c|c|c|c|c|}
\hline \multirow[b]{2}{*}{ Doc. } & \multirow[b]{2}{*}{ Ano } & \multicolumn{8}{|c|}{ Bispos } \\
\hline & & $\begin{array}{c}\text { Arcebispo } \\
\text { de Braga }\end{array}$ & $\begin{array}{c}\text { Bispo do } \\
\text { Porto }\end{array}$ & $\begin{array}{l}\text { Bispo de } \\
\text { Coimbra }\end{array}$ & $\begin{array}{c}\text { Bispo de } \\
\text { Lisboa }\end{array}$ & $\begin{array}{c}\text { Bispo de } \\
\text { Évora }\end{array}$ & $\begin{array}{l}\text { Bispo de } \\
\text { Lamego }\end{array}$ & $\begin{array}{c}\text { Bispo da } \\
\text { Guarda }\end{array}$ & $\begin{array}{c}\text { Bispo de } \\
\text { Viseu }\end{array}$ \\
\hline 58 & 1237 & $\begin{array}{c}\text { D. Silvestre } \\
\text { Godinho }\end{array}$ & $\begin{array}{c}\text { D. Pedro } \\
\text { Salvadores }\end{array}$ & - & - & D. Fernando & D. Paio & D. Vicente & D. Gil \\
\hline 59 & 1237 & - & - & - & - & - & - & - & - \\
\hline 67 & 1239 & $\begin{array}{c}\text { D. Silvestre } \\
\text { Godinho }\end{array}$ & $\begin{array}{c}\text { D. Pedro } \\
\text { Salvadores }\end{array}$ & $\begin{array}{c}\text { D. Tibúrcio } \\
\text { (eleito) }\end{array}$ & - & - & D. Paio & - & D. Gil \\
\hline 68 & 1239 & $\begin{array}{c}\text { D. Silvestre } \\
\text { Godinho }\end{array}$ & $\begin{array}{c}\text { D. Pedro } \\
\text { Salvadores }\end{array}$ & \begin{tabular}{|c|}
$\begin{array}{c}\text { D. Tibúrcio } \\
\text { (eleito) }\end{array}$ \\
\end{tabular} & - & - & D. Paio & D. Vicente & D. Gil \\
\hline 73 & 1240 & $\begin{array}{c}\text { D. Silvestre } \\
\text { Godinho }\end{array}$ & $\begin{array}{c}\text { D. Pedro } \\
\text { Salvadores }\end{array}$ & $\begin{array}{c}\text { D. Tibúrcio } \\
\text { (eleito) }\end{array}$ & - & D. Fernando & D. Paio & D. Vicente & D. Gil \\
\hline 84 & 1245 & - & - & D. Tibúrcio & - & - & - & - & - \\
\hline 85 & 1245 & - & - & D. Tibúrcio & - & - & - & - & - \\
\hline
\end{tabular}

Recebido em/Text submitted on: 10/02/13 Aceite em/Approved on: 23/07/13 